\title{
delta-Opioid Modulation of Striatal Dopaminergic Activity in Mice
}

\author{
Ashok K. Dua and Carl Pinsky
}

\begin{abstract}
Mu- and delta-opioid subtype receptor antagonists were tested in the mouse for their effects on vertical climbing activity, an index of striatal dopaminergic activity. The selective delta-opioid antagonist ICI 154129 (I/I) by itself enhanced vertical climbing activity in a dose-related manner, whereas the mu-opioid antagonist naloxone by itself was inactive on climbing behavior. Naloxone increased the climbing-stimulant effect of $\mathbf{I} / \mathbf{l}$. Unstimulated vertical climbing activity was reduced, and all opioidantagonist enhancement of climbing behavior was antagonized, by the competitive dopamine antagonist haloperidol in dose-related fashion. The observed motor-enhancement effect of a selective delta-opioid receptor antagonist is the first demonstration of physiologically-significant tonic activity on a central opioid receptor. Our observations suggest that $\mathrm{I} / \mathrm{l}$ may be useful clinically in striatal dopamine-deficient disease conditions such as parkinsonism.
\end{abstract}

RÉSUMÉ: Modulation de l'activité dopaminergique chez la souris par l'activité opiacée-delta Nous avons évalué chez la souris l'effet de certains antagonistes des récepteurs opiacés de sous-type Mu et delta sur leur capacité à grimper verticalement, capacité qui est un index de l'activité dopaminergique du striatum. Le ICI 154-129(I/1), antagoniste sélectif des récepteurs opiacés delta, lorsqu'employé seul, potentiait l'activité de façon graduée selon la dose, alors que la naloxone, antagoniste du récepteur opiacé Mu, était inactive par elle-même sur cette activité. La naloxone, par contre, augmente l'effet stimulant du I/1. L'halopéridol, un antagoniste compétitif de la dopamine, diminuait la capacité non stimulée de grimper verticalement, ainsi que toute potentiation de cette activité par les antagonistes opiacés. Cette stimulation d'un effet moteur par un antagoniste spécifique des récepteurs opiacées delta est la première démonstration d'une activité tonique physiologiquement significative sur un récepteur opiacé central. Ces observations suggèrent que le produit I/I pourrait être utile cliniquement dans des conditions ou maladies accompagnées de déficience dopaminergique striatale comme la maladie de Parkinson.

Can. J. Neurol. Sci. 1985; 12:60-64

Current medical therapy for Parkinson's disease is based on the use of drugs whose actions restore or augment dopaminergic neuroactivity in the dopamine-deprived neostriatum (Hornykiewicz, 1973a, b). The major approach, which arose from the observation that there is a deficiency of dopamine (DA) in the basal ganglia of brains from parkinsonian patients (Ehringer and Hornykiewicz, 1960), is the administration of the dopamine precursor, levodopa (Cotzias et al., 1976). Direct agonists of postsynaptic dopamine receptors also are often useful in parkinsonism, such drugs include apomorphine and its congeners (Cotzias et al., 1976) as well as ergot derivatives such as bromocriptine, lisuride and lergotrile (Calne, 1977, 1978; Goldstein et al., 1978; Lieberman et al., 1976). None of the foregoing agents provide permanent therapeutic benefit, nor do they arrest the course of the disease. Their efficacy eventually decreases and even painstaking regulation of dose and regimen fails to prevent progression of the disease. Concomitant with the loss of levodopa effectiveness there is a cumulative increase in deleterious side effects (e.g. hyperkinesia, behavioral changes and psychosis) (Marsden and Parkes, 1977; Weiner, 1982; Calne, 1983). Often, there is a gross and unacceptable alternation between hyperkinesia and akinesia (the "On-Off"' syndrome (Calne, 1977; Marsden and Parkes, 1977; Granerus, 1978). These side effects are generally attributed to levodopa overdose or underdose and to the lability of the presumed therapeutic region lying between the two extremes.

It is not unreasonable, in view of the foregoing, to suggest that some new pharmacological approach may be necessary before any improvement in the medical therapy of parkinsonism can be expected. We found it of interest that a significant depletion of opioid receptors has been observed in the caudate nucleus of brains taken from Parkinson's disease patients at postmortem (Reisine et al., 1979). The Jhamandas group (Marien and Jhamandas, 1983; Marien et al., 1983) has shown that delta-opioid receptor stimulation inhibits glutamate-stimulated release of DA from rat striatal slices in vitro. We therefore 
decided to test whether a putative physiological role for striatal delta-opioid receptors could be discerned in vivo. To do this we have studied the effects of a relatively specific delta-opioid antagonist on vertical climbing activity (VCA) in mice, since that behavior is well-established as a convenient in vivo index of activity at striatal dopaminergic synapses in the mouse (Costentin et al., 1975; Protais et al., 1976; Dascombe and Foote, 1981; Marcais et al., 1979) and rat (Protais et al., 1984). We report in this study that the delta-opioid antagonist N,N-Bisallyl-Tyr-Gly-Gly-psi-( $\mathrm{CH}_{2} \mathrm{~S}$-Phe-Leu-OH)(ICI 154 129; I/I) (Gormley et al., 1982; Shaw et al., 1982) by itself enhanced mouse-climbing activity in dose-related fashion, whereas the mu-antagonist naloxone by itself is inactive on climbing behavior. It was found also that naloxone increases the climbing-stimulant effect of $1 / 1$ and that the opioid antagonist enhancement of climbing behavior is antagonized by the competitive dopamine antagonist haloperidol in dose-related fashion.

\section{Methods}

\section{Animals, drugs and injections}

Swiss-Webster male mice, 20-25 g, were purchased from Canadian Breeding Laboratories, St. Constant, PQ. ICI 154 129 was a gift from ICI Pharmaceuticals, Macclesfield, haloperidol injectable (HALO) from McNeil Laboratories (Canada) and naloxone hydrochloride (NLX) from Du Pont de Nemours. NLX and $\mathrm{I} / \mathrm{l}$ were administered to each mouse by subcutaneous (SC), and HALO by intraperitoneal (IP), injection. Volume of injection for each drug or control solution was $0.1 \mathrm{ml}$ for every $10 \mathrm{~g}$ body weight. Drugs were administered to each mouse at 30 min prior to evaluation of VCA. Responses were measured to the following treatments: $\mathrm{I} / \mathrm{l}$ at 1,3 or $10 \mathrm{mg} \mathrm{kg}^{-1} \mathrm{SC}$; NLX at $0.1,1$ or $5 \mathrm{mg} \mathrm{kg}^{-1} \mathrm{SC}$; $\mathrm{I} / \mathrm{l}$ at $3 \mathrm{mg} \mathrm{kg}^{-1} \mathrm{SC}$ followed, within seconds, by SC injection of NLX at $1 \mathrm{mg} \mathrm{kg}^{-1}$; HALO at 0.1 or $0.5 \mathrm{mg} \mathrm{kg}^{-1} \mathrm{IP}$, each either alone or followed within seconds by injections either of $I / I$ at $10 \mathrm{mg} \mathrm{kg}^{-1}$ or of $I / 1$ at $3 \mathrm{mg} \mathrm{kg}^{-1} \mathrm{SC}$ and NLX at $1 \mathrm{mg} \mathrm{kg}^{-1} \mathrm{SC}$; control IP injection ("sham" injection: needle penetration of abdominal wall with no substance injected).

\section{Evaluation of VCA}

Mice were placed individually in specially-built circular cages (12 $\mathrm{cm}$ dia $\times 16 \mathrm{~cm} \mathrm{ht}$, the cage walls consisting of vertical stainless steel rods of $2.5 \mathrm{~mm}$ dia spaced $1 \mathrm{~cm}$ apart; the circular floor and cover of each cage were turned from sheet acrylic). The design of these cages represented slight modifications of the mouse-climbing apparatus described by Protais et al. (1976). Four cages were viewed simultaneously by the experimenter, each cage being both acoustically and visually isolated from its neighbor. A graduated quantitative value for climbing activity was assessed for the individual mouse in each cage, according to the following system for numerical scoring of VCA: $0=$ mouse sitting or standing on cage floor without touching a vertical rod; $1=$ sitting on floor while grasping a bar with one forepaw or hindpaw; 2 = grasping one or two rods with both forepaws but with an angle of less than $45^{\circ}$ between the body long axis and the cage floor; $3=$ as in (2) but with body axis/floor angle greater than $45^{\circ} ; 4=$ standing upright while grasping rods with both forepaws but with both hindpaws touching cage floor; 5 = climbing on rods with all four legs off the floor. VCA scores for each mouse were sampled at 30-sec intervals, a score being assigned to the mouse in any given cage when a miniature red light-emitting diode, not visible to the animal, was energized under the cage for a duration of 2 secs. The visual signal was stepped sequentially from cage to cage by a hardwired microchip controller (Pinsky et al., unpublished) in a repeating sequence for a total observation period of $30 \mathrm{~min}$ after each drug treatment. Thus the observer assigned a score for each individual mouse at $30-\mathrm{sec}$ intervals for a total observation period of $30 \mathrm{~min}$, generating a total of 60 sampled scores for each mouse over the 30 -min period of observation. The sampled scores were summed for all animals in a given treatment group, and expressed as mean 30-min VCA scores per animal for that group.

\section{Experimental design and statistical analysis}

All experiments were carried out between 1000 and 1300 hours, in temperature- and humidity-controlled rooms. Observations were made by an independent observer who was unaware of the nature of the administered drug treatments. At the end of the experiment VCA scores were compiled and tested for significance of group interactions by analysis of variance (ANOVA), followed by Duncan's test for multiple comparisons. The extent to which there was a dose-response relationship between VCA responses and any given drug treatment was examined by a least-squares linear regression analysis of drug dose on the magnitude of response. Sham injection was taken to represent zero dose for all substances. Existence of a dose-response relationship was inferred when the correlation coefficient for the regression line was found significantly different from zero, by two-tailed analysis (Bulmer, 1965).

\section{RESUlts}

A basal level of unstimulated climbing activity was observed in the sham injection group. This basal activity was significantly suppressed by HALO at 0.1 and at $0.5 \mathrm{mg} \mathrm{kg}^{-1}$, in doserelated fashion (Fig. 1, Table 1 ). I/l, over the dose range of 1 to $10 \mathrm{mg} \mathrm{kg}^{-1} 1$, consistently increased VCA to levels above the unstimulated value; the difference between VCA scores after sham injection and after $10 \mathrm{mg} \mathrm{kg}^{-1} \mathrm{I} / \mathrm{l}$ was statistically significant, as was the dose-response relationship for $I / /$ plotted against VCA (Fig. 1, Table 1). I/l enhancement of climbing activity was significantly suppressed by HALO, which exerted this antagonism also in a dose-related manner (Fig. 1, Table 1). NLX by itself, in the dose range of 0.1 to $5 \mathrm{mg} \mathrm{kg}^{-1}$, had no significant effect on climbing activity (Fig. 2, Table 1). In combination with $\mathrm{I} / \mathrm{I}$ given at $3 \mathrm{mg} \mathrm{kg}^{-1}$, however, $\mathrm{NLX}$ at $1 \mathrm{mg} \mathrm{kg}^{-1}$ significantly increased the $I / /$ enhancement of climbing activity (Figs. 2, 3); mean VCA scores for mice treated with $\mathrm{I} / 1$ at $3.0 \mathrm{mg} \mathrm{kg}$ followed by NLX at $1.0 \mathrm{mg} \mathrm{kg}^{-1}$ (Fig. 3, Group B) were significantly greater $(p \leqslant 0.01)$ than those for mice treated with $\mathrm{I} / 1$ alone at $3.0 \mathrm{mg} \mathrm{kg}^{-1}$ (Fig.1, Group E). This synergistic effect of NLX with $\mathrm{I} / \mathrm{l}$ was significantly antagonized by HALO in a dose-related manner (Fig. 3, Table 1).

\section{Discussion}

The observation of unstimulated VCA in mice suggests that this spontaneous activity is the motor expression of ongoing neural events in some tonically-active central nervous system 
pathway in that species. Low doses of haloperidol, a specific competitive antagonist of DA at postsynaptic sites (Seeman, 1980), suppressed VCA to below basal levels in dose-related fashion. Earlier work of other investigators (Constentin et al., 1975; Protais et al., 1976; Marcais et al., 1979; Wilcox et al., 1980; Dascombe and Foote, 1981 ; Protais et al., 1984) supports the concept that the haloperidol-induced diminution of VCA was due to an action of the blocking agent at striatal dopaminergic synapses. The observed ability of haloperidol to suppress $\mathrm{I} / \mathrm{l}$-induced stimulation of VCA, further, supports the concept that the effect of $I / 1$ on climbing is due to augmentation of striatal dopaminergic neurotransmission.

Our results suggest a close relationship between dopaminergic neurotransmission and opioid receptor function in the mouse basal ganglia. Opioid receptors in the corpus striatum and substantia nigra of rodents are located mainly on the dendrites, somata and nerve terminals of dopamine-containing neurons.
Recent autoradiographic studies have demonstrated two distinct subpopulations of striatal opioid receptors. Mu-opioid receptors have a clustered distribution on the cell bodies while deltaopioid receptors show a diffuse distribution on DA-containing nerve terminals (Goodman et al., 1980; Bowen et al., 1981; Atweh and Kuhar, 1983). Moreover, there is a twofold predominance of delta- over mu-opioid receptor sites in rat striatum (Fields et al., 1980). Mu-receptor agonists such as met-enkephalin and morphine increase the turnover rate of striatal DA and enhance its synthesis, both effects being naloxone-sensitive (Wand et al., 1973; Biggio et al., 1978; Iwatsubo, 1982). These observations suggest that the mu-opioid receptors associated with dopamine-rich sites in the nigrostriatal pathway (Pollard et al., 1978; Ninkovic et al., 1981) might be part of an endorphinergic mechanism for regulation of nigrostriatal dopamine metabolism (Havemann et al., 1982). This possibility must be considered in conjunction with the observations by Marien and Jhamandas

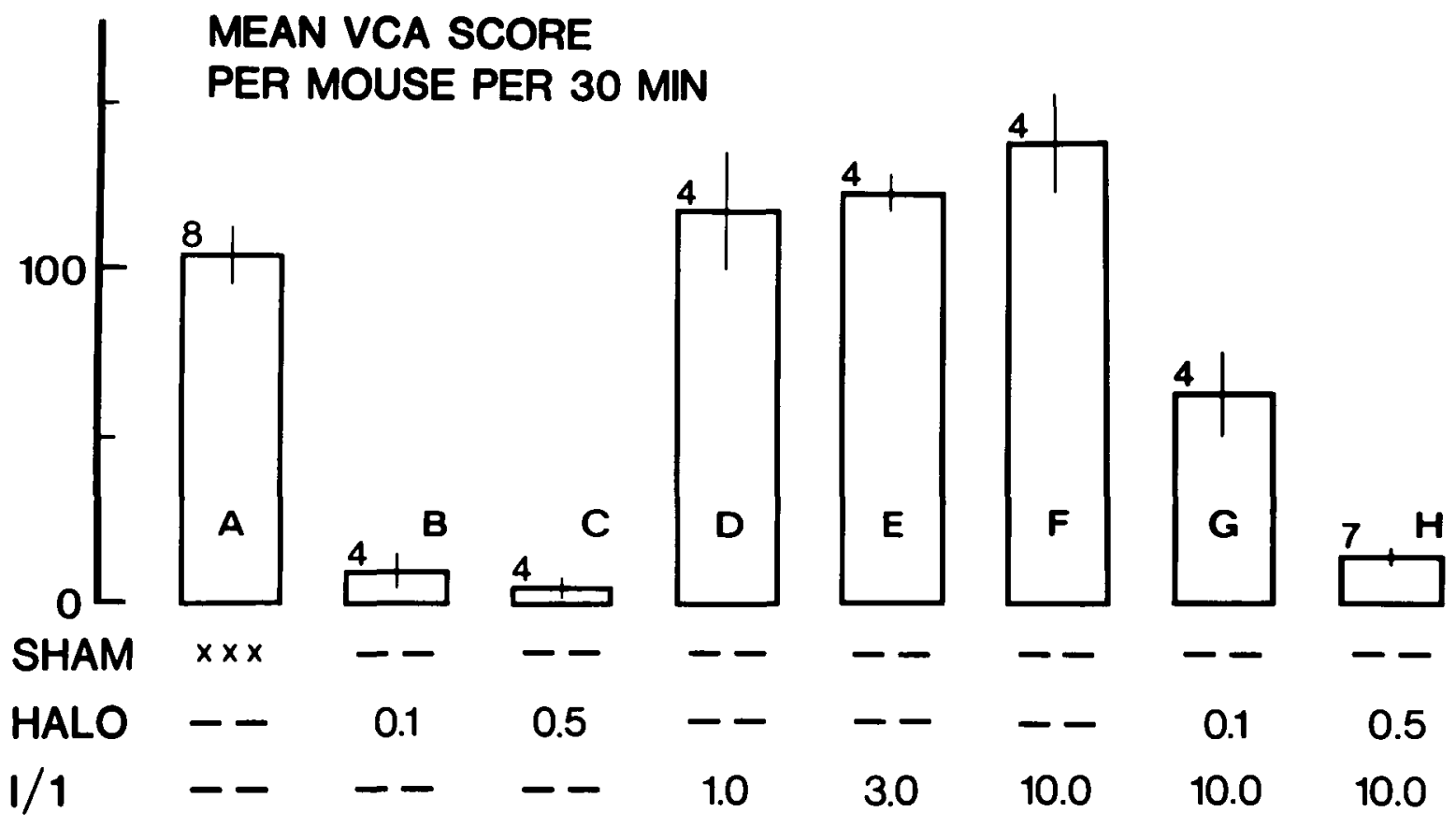

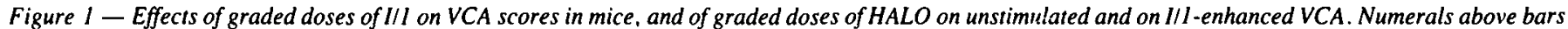
indicate number of mice in treatment group. Heights of bars and their lines indicate means \pm standard error. Symbols below bars: $(X X X)=$ administration of sham injection; $(--)=$ no injection of substance indicated at left-hand end of line; numerical values represent administered doses, in mg $\mathrm{kg}^{-1}$, of substances indicated at left-hand end of line. Abbreviations and other details, see text.

Table 1: Analysis of correlation between dose of substance and magnitude of VCA response.

\begin{tabular}{|c|c|c|c|c|}
\hline $\begin{array}{l}\text { Substance Tested: } \\
\text { Test Circumstance }\end{array}$ & $\begin{array}{l}\text { Doses Tested } \\
\left(\mathrm{mg} \mathrm{kg} \mathbf{k g}^{-1}\right)\end{array}$ & $\begin{array}{l}\text { Correlation } \\
\text { Coefficient }\end{array}$ & $\mathbf{P}$ & $\begin{array}{l}\text { Illustrated in } \\
\text { Figure No. }\end{array}$ \\
\hline HALO; tested on unstimulated VCA & $0,0.1,0.5$ & -0.71 & $<0.001$ & 1 \\
\hline $\mathrm{V} / 1$; tested on unstimulated VCA & $0,1,3,10$ & +0.45 & $<0.05$ & 1 \\
\hline $\begin{array}{l}\text { HALO; tested on VCA enhanced } \\
\text { by } \mathrm{I} / 110 \mathrm{mg} \mathrm{kg}^{-1}\end{array}$ & $0,0.1,0.5$ & -0.87 & $<0.001$ & 1 \\
\hline NLX; tested on unstimulated VCA & $0,0.1,1,5$ & -0.05 & $<0.8$ (NS) & 2 \\
\hline $\begin{array}{l}\text { HALO; tested on VCA enhanced by } \\
\text { combination of } 1 / 13 \mathrm{mg} \mathrm{kg}^{-1} \text { and } \\
\text { NLX } 1 \mathrm{mg} \mathrm{kg}^{-1}\end{array}$ & $0,0.1,0.5$ & -0.77 & $<0.001$ & 3 \\
\hline
\end{tabular}

NS = not significant. Other abbreviations and details in text. 


\section{MEAN VCA SCORE PER MOUSE PER 30 MIN}
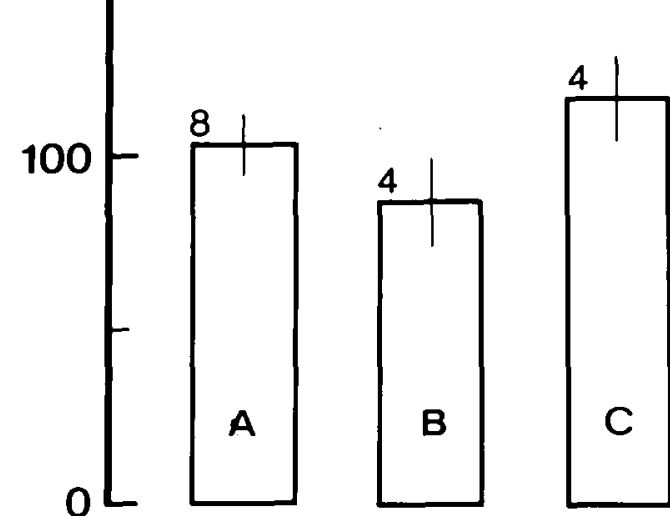

SHAM

$\times \times x$

NLX

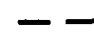

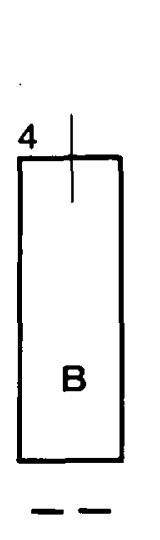

0.1
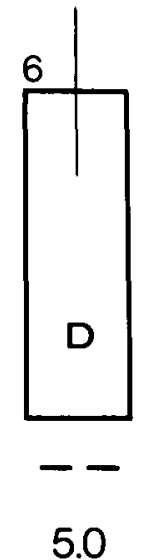

Figure 2 - Effects of graded doses of NLX on VCA scores in mice. Symbols and legend as in Fig. $l$.

\section{MEAN VCA SCORE}

PER MOUSE PER 30 MIN
$100-$

SHAM $x \times x$

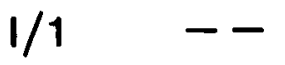

NLX

HALO

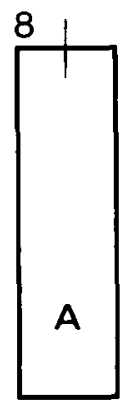

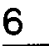

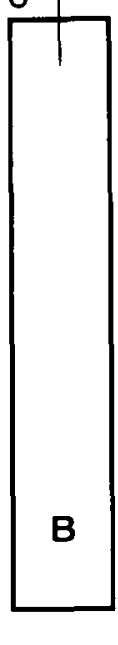

3.0

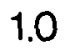

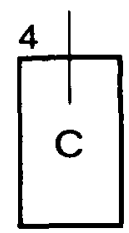

4

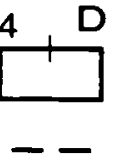

3.0

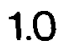

located on dopaminergic neurons in the nigrostriatal axis while delta-opioid receptors on the same neurons are part of a physiological system for the regulation of DA release from nerve terminals. It appears reasonable to propose that the mode of action for the enhancement by $\mathrm{I} / 1$ of mouse climbing activity is related to the ability of $1 / 1$ to block delta-opioid receptors located on dopaminergic nerve terminals. In the mouse such receptors appears to be under the tonic control of endogenous delta-opioid agonists whose agonism suppresses the release of dopamine from the terminal. In contrast mu-opioid receptors associated with striatal dopaminergic neurotransmission seem not to be tonically activated since the mu-opioid antagonist naloxone by itself had no effect, over a wide range of doses, on climbing activity.

The unexpected profound synergism between ineffective doses of naloxone and a median-effective dose of $\mathrm{I} / \mathrm{h}$ on the enhancement of mouse climbing activity cannot be explained solely in terms of known actions of mu-opioid receptor agonists on striatal dopamine release. A similar synergism between $\mathrm{I} / \mathrm{l}$ and naloxone has been demonstrated elsewhere on seizure activity in the rat (Cowan and Gmerek, 1982). The observed effect of a selective delta-opioid receptor antagonist on mouse climbing activity represents, to our best knowledge, the first evidence of physiologically significant tonic activity on a central opioid receptor. It is interesting that the central delta-opioid receptor system appears to be tonically active while its mu-opioid counterpart is not; it would be useful to examine the possible generality of this differentiation in endogenous opioid systems. The development and use of selective antagonists for the putative opioid receptor subtypes will permit further insight as to which opioid receptor systems are tonically active and physiologically important at central and peripheral sites.

In the specific instance of the climbing activity tested here it appears that blockade of striatal delta-opioid receptors with I/I can promote dopaminergic neurotransmission in that brain region. The mu-opioid antagonist naltrexone has been tested clinically in patients with Parkinson's disease and was ineffective (Nutt et al., 1978). Our own results suggest that a delta-opioid antagonist might prove effective in parkinsonism, especially if combined with a mu-opioid antagonist. We are currently examining the properties of $\mathrm{I} / \mathrm{l}$ in preclinical studies aimed at such clinical possibilities. A brief account of part of this work has been presented in abstract form (Dua and Pinsky, 1984).

\section{ACKNOWLEDGEMENTS}

This work was supported by the American Parkinson's Disease Association, the Parkinson Foundation of Canada, Medical Research Council of Canada, Faculty of Medicine Dean's Fund and Faculty Development Fund, University of Manitoba Research Grants Committee Fund and Career Access Program of Employment and Immigration Canada. We are grateful to J.S. Shaw and R. Cotton of ICI Macclesfield for generous gift of the experimental substances of ICI 154,129. We thank Ranjan Bose and F.S. LaBella for helpful discussion, E. Brockhausen, and J. Delaive for excellent technical assistance.

\section{REFERENCES}

(1983) and by Marien et al. (1983) that delta-opioid receptor agonism can inhibit the glutamate-stimulated release of DA in rat striatum. The sum of such observations supports the concept that modulation of turnover and synthesis of DA at synapses represents a physiological function for mu-opioid receptors

Atweh SF, Kuhar MJ (1983) Distribution and physiological significance of opioid receptors in the brain Br. Med. Bull. 39: 47-52.

Biggio G, Casu M, Corda MG, Dibello C, Glessa GL (1978) Stimulation of dopamine synthesis in caudate nucleus by intrastriatal enkephalins and antagonism by naloxone. Science 200: $552-554$. 
Bowen WD, Gentleman S, Herkenham M, Pert CB (1981) Interconverting $\mathrm{mu}$ and delta forms of the opiate receptor in rat striatal patches. Proc. Natl. Acad. Sci. 78: 4818-4822.

Bulmer MG (1965) Principles of statistics. Oliver and Boyd (publ.), Edinburgh. 183-203.

Calne DB (1977) Developments in the pharmacology and therapeutics of parkinsonism. Ann. Neurol. 1: 111-119.

Calne DB (1978) Parkinsonism: clinical and neuropharmacologic aspects. Postgrad. Med. 64: 82-88.

Calne DB (1983) Current views on Parkinson's Disease. Can. J. Neurol. Sci. 10: $11-15$.

Constentin J, Protais P, Schwartz JC (1975) Rapid and dissociated changes in sensitivities of different dopamine receptors in the mouse brain. Nature 257: 405.407.

Cotzias GC, Papavasiliou PS, Tolosa ES, Mendez JS, Bell-Midura M (1976) Treatment of parkinsonism with apomorphines: possible role of growth hormone. N. Engl. J. Med. 294: 567-572.

Cowan A, Gemerek DE (1982) In vivo studies with ICI 154 129, a putative delta receptor antagonist. Life Sci. 31: 2213-2216.

Dascombe MJ, Foote GG (1981) Intrastriatal injection of apomorphine and climbing behavior in chronically cannulated mice. Br. J. Pharmac. 73: $236 \mathrm{P}$.

Dua AK, Pinsky C (1984) delta-Opiate receptor blockade promotes striatal dopamine-specific climbing activity in mice and suggests a novel antiparkinsonism therapy. Federation Proc. 43: 654.

Ehringer H, Hornykiewicz O (1960) Verteilung von Noradrenalin und Dopamin (3-hydroxytyramin) im Gehirn des Menschen und ihr Verhalten bei Erkrankungen des extrapyramidalen Systems. Klin. Wochenschr. 38: 1236-1239.

Fields HL, Emson PC, Leigh BK, Gilbert RFT, Iversen LL (1980) Multiple opiate receptor site on primary afferent fibres. Nature 284: 351-353.

Goldstein M, Lieberman A, Battista AF, Lew JY, Matsumoto Y (1978) Experimental and clinical studies on bromocriptine in the parkinsonian syndrome. Acta Endocrinol. (Kbh.) 88: Suppl. 216, 57-66.

Goodman RR, Snyder SH, Kuhar MJ, Young WS (1980) Differentiation of delta and mu opiate receptor localization by light microscopic autoradiography Proc. Natl. Acad. Sci. U.S.A. 77: 6239-6253.

Gormley JJ, Morley JS, Priestley T, Shaw JS, Turnbull MJ, Wheeler H (1982) In vivo evaluation of the opiate delta receptor antagonist ICI 154, 129. Life Sci. 31: 1263-1266.

Granerus AK (1978) Factors influencing the occurence of "on-off" symptoms during long-term treatment with L-dopa. Acta. Med. Scand. 203: 75-81.

Havemann U, Turski L, Kuschinsky K (1982) Role of opioid receptors in the substantia nigra in morphine-induced muscular rigidity. Life Sci. 31: 2319-2322.

Hornykiewicz O (1973a) Dopamine in the basal ganglia. Br. Med. Bull. 29: $172-178$
Hornykiewicz O (1973b) Parkinson's disease from brain homogenate to treatment. Federation Proc. 32: 183-190.

Iwatsubo K (1982) Narcotic analgesics and nirostriatal dopaminergic neurons. TIPS, 3: 64-66.

Lieberman A, Kupersmith M, Gopinathan G, Estey E, Goodgold A, Goldstein M (1976) Treatment of Parkinson's disease with bromocriptine. N. Engl. J. Med. 295: 1400-1404.

Marcais H, Protais P, Costentin J (1979) Hypersensitivity of the climbing behavior response to apomorphine induced by a short depression of dopaminergic neuron activity. Neuropharmacol. 18: 845-849.

Marien M, Jhamandas K (1983) Release of endogenous dopamine (DA) from rat striatum in vitro: effects of L-glutamic acid (l-glu) and a delta opioid agonist. Soc. for Neurosci. Abst. 9: 587.

Marien M, Brien J, Jhamandas K (1983) Regional release of [ $\left.{ }^{3} \mathrm{H}\right]$ dopamine from rat brain in vitro: effects of opioids on release induced by potassium, nicotine, and L-glutamic acid. Can. J. Physiol. Pharmacol. 61: 43-60.

Marsden CD, Parkes JD (1977) Success and problems of long-term levodopa therapy in Parkinson's Disease. The Lancet 1: 345-349.

Ninkovic M, Hunt SP, Emson PC, Iversen LL (1981) The distribution of multiple opiate receptors in bovine brain. Brain Res. 214: 163-167.

Nutt JG, Rosin AJ, Eisler T, Calne DB, Chase TN (1978) Effects of an opiate antagonist on the movement disorders. Arch. Neurol. 35: 810-811.

Pollard H, Llorens C, Schwartz JC, Gros C, Dray F (1978) Localization of opiate receptors and enkephalins in the rat striatum in relationship with the nigro-striatal dopaminergic system: Lesion studies. Brain Res. 151: 392-393.

Protais P, Costentin J, Schwartz JC (1976) Climbing behavior induced by apomorphine in mice. A simple test for the study of dopamine receptors in striatum. Psychopharmacol. 50: 1-6.

Protais P, Bonnet J-J, Constentin J, Schwartz JC (1984) Rat climbing behavior elicited by stimulation of cerebral dopamine receptors. Naunyn-Schm. Arch. Pharmacol. 325: 93-101.

Reisine TD, Rossor M, Spokes E, Iversen LL, Yamamura HI (1979) Alterations in brain opiate receptors in Parkinson's disease. Brain Res. 173: 378-382.

Seeman P (1980) Brain dopamine receptors. Pharmacol. Rev. 32: 229-313.

Shaw JS, Miller L, Turnbull MJ, Gormley JJ, Morley JS (1982) Selective antagonist at the opiate delta-receptor. Life Sci. 31: 1259-1261.

Wand P, Kuschinsky K, Sontag KH (1973) Morphine-induced muscular rigidity in rats. Eur. J. Pharmacol. 24: 189-193.

Weiner M (1982) Update on antiparkinsonian agents. Geriatrics 37: $81-91$.

Wilcox RE, Smith RV, Anderson JA, Riffee WH (1980) Apomorphineinduced stereotypic cage climbing in mice as a model for studying changes in dopamine receptor sensitivity. Pharmacol. Biochem. Behav. 12: 29-33. 